\title{
PEMANFAATAN JARINGAN KOMPUTER UNTUK APLIKASI IPTV (INTERNET PROTOCOL TELEVISION) STUDI KASUS AKATEL SANDHY PUTRA PURWOKERTO \\ Galih Sasmi Ramdhani ${ }^{1}$, Wahyu Pamungkas ${ }^{2}$, Yana Yuniarsyah $^{3}$ \\ 1, 2 \& 3 Akatel Sandhy Putra Purwokerto \\ galih06@yahoo.com ${ }^{1}$,wahyu_pamungkas@ hotmail.com ${ }^{2}$, sawahlega@yahoo.com ${ }^{3}$
}

\begin{abstract}
ABSTRAKSI
Internet Protocol Television (IPTV) adalah suatu pengembangan baru dalam software komunikasi client-server yang mem-broadcast video yang berkualitas tinggi melalui jaringan internet protocol. IPTV melayani baik siaran langsung (live) maupun program atau video yang tersimpan di server. Streaming adalah sebuah teknologi untuk memainkan file video atau audio secara langsung ataupun dengan prerecorded dari sebuah mesin server. File video atau audio yang terletak pada server dapat secara langsung dijalankan pada komputer client sesaat setelah ada permintaan dari users sehingga proses download yang menghabiskan waktu cukup lama dapat dihindari. Digital Video Broadcasting (DVB) adalah salah satu sistem yang digunakan untuk mentransmisikan siaran TV / Video digital hingga sampai ke pengguna akhir (end-user). Proses Transmisi siaran TV umumnya masih menggunakan metode analog, maka dengan adanya streaming TV channel berbasis DVB merupakan suatu perkembangan distribusi siaran televisi yang tadinya secara analog menjadi digital. Oleh karena itu pada penelitian ini akan dibahas mengenai aplikasi IPTV yang berbasis DVB dengan metode streaming pada Ubuntu 9.04 yang merupakan distro Linux dengan media transmisi Wireless LAN Akatel Sandhy Putra Purwokerto. Metode streaming yang digunakan adalah broadcast yaitu pengiriman data, dimana data dikirimkan ke banyak titik sekaligus, tanpa melakukan pengecekan apakah titik tersebut siap atau tidak, atau tanpa memperhatikan apakah data itu sampai atau tidak. Contoh penggunaan sistem ini adalah siaran televisi dan radio.
\end{abstract}

Kata kunci: IPTV, Streaming, DVB, Broadcast, WLAN, Linux.

\begin{abstract}
Internet Protocol Television (IPTV) is a new development in software client-server communication that makes high-quality video broadcasts through the internet protocol network. IPTV serve either directly or broadcast program or video files stored on the server. Streaming is a technology for playing video or audio file directly or with pre-Recorded from a server machine. Video or audio file located on a server can be directly executed on the client computer as soon as there is demand from users, so the download process that spends a long time can be avoided. Digital Video Broadcasting (DVB) is one of the systems used to transmit broadcast TV / digital video, even to the end user. TV Transmission process is generally still using an analog method, and with streaming TV based on DVB channel is a broadcast television distribution developments that had an analog to digital. Therefore in this thesis will discuss about the DVB-based IPTV applications using streaming on Ubuntu 9.04 which is a Linux distro with Wireless LAN transmission medium Akatel Sandhy Putra Purwokerto. The method used is the broadcast stream that is sending data, where data is transmitted to many points at once, without checking whether the point has been made ready or not, or regardless of whether the data is up or not. Example usage of this system is the television and radio broadcasts.
\end{abstract}

Keywords: IPTV, Streaming, DVB, Broadcast, WLAN, Linux.

\section{PENDAHULUAN}

Berkembangnya teknologi jaringan komputer dan multimedia pada saat ini telah mendorong munculnya berbagai aplikasi layanan komunikasi yang bersifat interaktif, salah satunya adalah IPTV (Internet Protocol Television). IPTV merupakan suatu layanan multimedia dalam bentuk televisi, video, audio, text, graphic, data yang disalurkan ke pelanggan melalui jaringan IP (Internet Protocol), yang dijamin kualitasnya (QoS), keamanannya (Security), keandalannya (realibility) dan memungkinkan komunikasi dengan pelanggan secara dua 
arah atau interaktif (interactivity) secara real time.

IPTV bukan sekedar siaran TV yang dapat dinikmati melalui jaringan IP saja, tetapi IPTV juga mempunyai fasilitas/kemampuan yang lebih seperti mampu menyediakan layanan multimedia dan interaktif secara real time, melalui pesawat televisi standar yang terhubung dengan penyedia layanan IPTV melalui saluran kabel (Wireline, Fiber Optic). Kualitas layanan gambar, suara dan keamanannya dijamin penuh oleh penyedia IPTV melalui suatu jaringan tertutup (closed distribution network) yang dikelola secara profesional dan mengacu pada standar layanan yang berlaku ${ }^{[1]}$. Cara untuk penerapan aplikasi IPTV ini adalah dengan menggunakan layanan DVB (Digital Video Broadcasting) yaitu salah satu sistem yang digunakan untuk mentransmisikan siaran TV/Video digital hingga ke pengguna akhir (end user).

Akatel Sandhy Putra Purwokerto memiliki fasilitas untuk penerapan aplikasi IPTV yang berbasis DVB dengan metode streaming diantaranya yaitu : antena parabola, DVB Card USB, Software DVBWorld, wireless access point, Laboratorium Komputer dan jaringan lokal area. Sehingga dengan adanya fasilitas tersebut diatas maka aplikasi IPTV yang berbasis DVB ini dapat diterapkan pada jaringan lokal area di Akatel Sandhy Putra Purwokerto.

\section{METODOLOGI PENELITIAN}

Metode penelitian yang digunakan dalam penelitian ini adalah:

a. Studi Literatur

Dilakukan dengan mengumpulkan referensi dari berbagai literatur yang berkaitan dengan jaringan komputer, IPTV, streaming, Operating System Ubuntu 9.04 dan Digital Video Broadcasting (DVB).

b. Praktikum

Yaitu melakukan praktik penginstalan DVB Card USB pada Ubuntu 9.04, penginstalan Kaffeine Player pada sisi server dan penginstalan VLC pada sisi client.

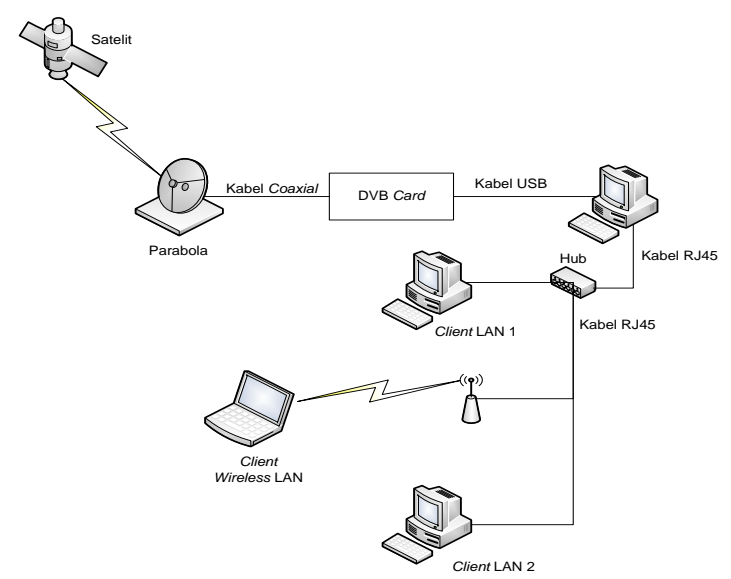

Gambar 1. Konfigurasi Jaringan.

Gambar 1 adalah konfigurasi dari jaringan client-server yang dibuat dalam penelitian ini. Penjelasan dari gambar diatas yaitu Satelit Telkom-1 memancarkan sinyal siaran TV digital yang nantinya ditangkap oleh antena parabola melalui LNB (Low Noise Block), dari antena parabola sinyal tersebut masuk ke DVB Card melalui kabel coaxial. Selanjutnya dari DVB Card sinyal tersebut 
diolah menjadi data informasi berupa siaran TV digital yang kemudian ditransmisikan ke komputer server melalui kabel USB. Siaran yang sudah diterima komputer server kemudian di distribusikan ke komputer client-client melalui media transmisi kabel LAN dan wireless LAN yang ada di Akatel Sandhy Putra Purwokerto.

Dalam melaksakanan metode praktikum ini proses perancanangan dan instalasi yang dilakukan adalah:

\section{A. Instalasi DVB Card pada Ubuntu}

\subsection{4}

Berikut adalah langkah instalasi DVB Card pada Ubuntu 9.04 :

1. Pada saat akan melakukan penginstalan DVB Card, terlebih dahulu DVB Card dihubungkan dengan antena parabola menggunakan kabel coaxial.

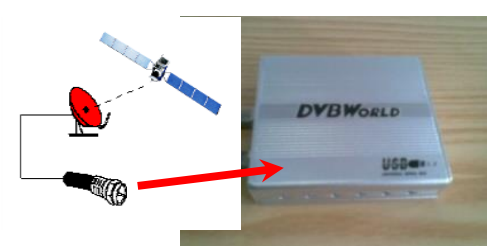

Gambar 2. Pemasangan Kabel Coaxial pada DVB Card.

2. Kemudian dilanjutkan dengan memasang kabel power pada DVB Card.

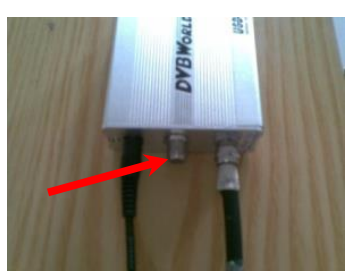

Gambar 3. Pemasangan Catu Daya pada DVB Card.
3. Kabel USB yang telah terpasang pada DVB Card dihubungkan ke komputer server melalui port USB yang tersedia pada komputer. Port USB yang digunakan adalah port USB 2.0.

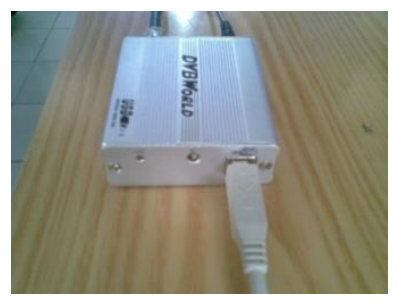

Gambar 4. Port USB pada DVB Card.

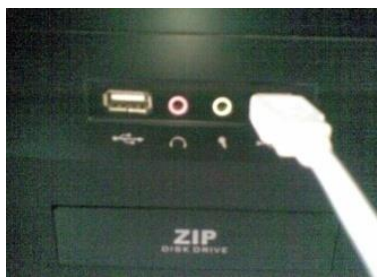

Gambar 5. Port USB pada Komputer.

Apabila antena dan DVB Card telah terhubung dan terpasang pada komputer server dilanjutkan dengan penginstalan. Sebelum melakukan penginstalan DVB Card, maka dilakukan pengecekan apakah DVB hardware sudah terdeteksi komputer atau belum.

4. Mendeteksi DVB hardware pada Ubuntu 9.04

Langkah pertamanya adalah dengan mengetikan perintah dmesg |grep dvb dan melihat hasilnya pada layar monitor

\section{B. Instalasi Kaffeine Player pada Server}

Langkah untuk penginstalan Kaffeine Player pada server yaitu dengan cara mengakses Applications $\rightarrow$ Accessories

\section{$\rightarrow$ Terminal}


Setelah masuk halaman terminal, kemudian mengetik perintah sudo apt-get install kaffeine

\section{Install VLC pada Client}

Langkah-langkah instalasi VideoLAN Client adalah sebagai berikut :

1. Langkah awal adalah harus memiliki software VideoLAN Client. Software VideoLAN Client dapat didownload dari internet pada situs berikut :

http://download.cnet.com/VLC-MediaPlayer/3000-13632 4-11017757.html

2. Setelah dapat mendownload software, proses instalasi dimulai. Proses instalasi diawali dengan memilih bahasa yang akan digunakan.

3. Memulai proses instalasi software VLC 9.8 .

4. Memilih next maka muncul pernyataan izin penggunaan software VideoLAN Client (VLC). Pada tampilan pernyataan ini dipilih I Agree yang berarti "saya setuju".

5. Melakukan pemilihan komponen dimana VideoLAN Client akan di instalasi. Selanjutnya memilih Start Menu dan Desktop Shortcut, lalu next.

6. Menyimpan file yang ada di VideoLAN Client yang ditempatkan pada 'Disk C'. Memilih install.

7. Setelah itu maka VLC sedang di proses penginstalasian.

8. Instalasi telah selesai kemudian memilih Finish.

\section{KONFIGURASI}

\section{A. Mendapatkan Siaran TV}

Untuk mendapatkan siaran TV dilakukan dengan cara membuka dialog Channels dari menu DVB, dan melakukan Start Scan.

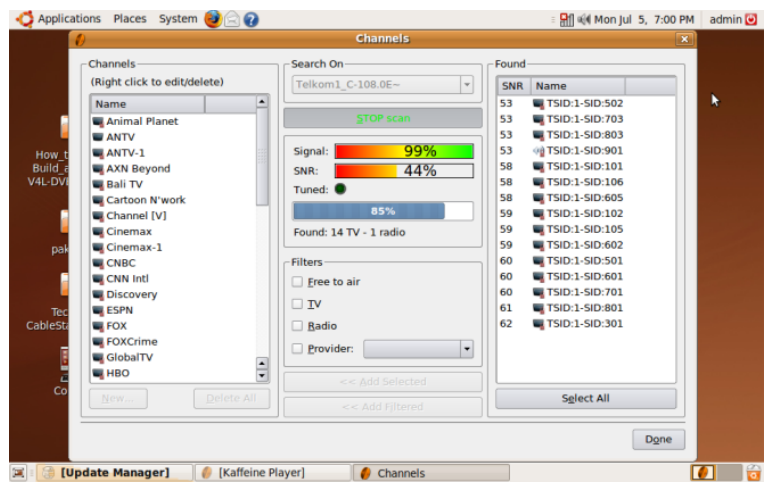

Gambar 6. Proses Scanning.

Pemindaian ini berlangsung lama, setelah selesai memilih siaran yang akan dimasukkan ke daftar menu Channels dan memilih Add Selected atau menggunakan filter dan memilih Add Filtered setelah itu memilih Done.

\section{B. Pengaturan Broadcast TV Channel}

Kaffein dapat menyiarkan beberapa channel dari DVB pada suatu Wireless LAN dengan cara membuka dialog konfigurasi DVB dan menuju ke halaman Broadcasting untuk menetapkan alamat dan port.

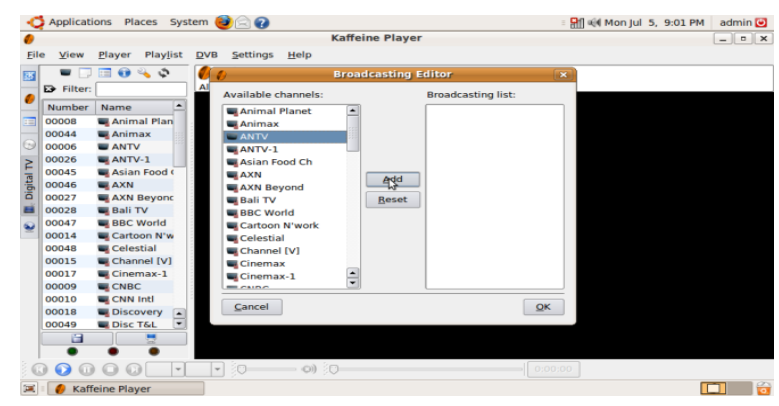

Gambar 7. Tampilan Broadcast ke Client

\section{Analisa Hasil Streaming}

1. Proses Scanning Siaran TV 
Saat melakukan scanning siaran TV, untuk mendapatkan hasil siaran TV yang kualitasnya baik itu tergantung dari standar perangkat receiver yang digunakan, berdasarkan hasil percobaan yang dilakukan untuk DVB-S minimal Signal $80 \%$ dan SNR nya itu $60 \%$, sebab jika Signal dan SNR kurang dari batas minimalnya, maka siaran TV yang diterima tidak terkunci.

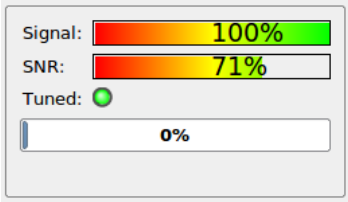

Gambar 8. Signal dan SNR.

\section{Pengujian pada Sisi Server}

Pengujian disisi server akan dinyatakan berhasil apabila server sudah dapat mendistribusikan siaran TV channel yang ada pada satelit Telkom-1. Siaran TV yang diterima oleh server tersebut yang kemudian akan dikirimkan ke client, apabila client tidak dapat menerima siaran yang ada pada server, maka server dianggap tidak berhasil. Untuk mengetahui server sudah berhasil mengirimkan paket data streaming siaran TV channel ke client caranya yaitu dengan melakukan test ping ke IP address client.

\section{Pengujian pada Sisi Client}

Pengujian pada sisi client dapat dilakukan apabila client sudah ter-install software VLC media player, yang nantinya bertugas untuk memutar video atau audio yang ada pada server multicast. Pengujian di sisi client ini akan dinyatakan berhasil apabila sudah menerima hasil streaming dari server. Langkah-langkah untuk mengetahui hasil pengujian client yang dinyatakan berhasil yaitu dengan cara mengakses streaming server multicast dengan menggunakan VLC media player seperti dibawah ini :

* Membuka aplikasi VLC media player pada client

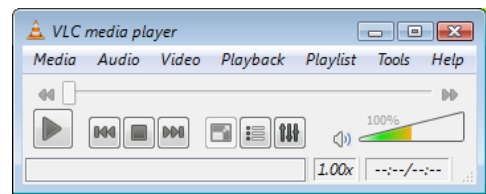

Gambar 9. Tampilan aplikasi VLC media player.

* Memilih menu File VLC media player

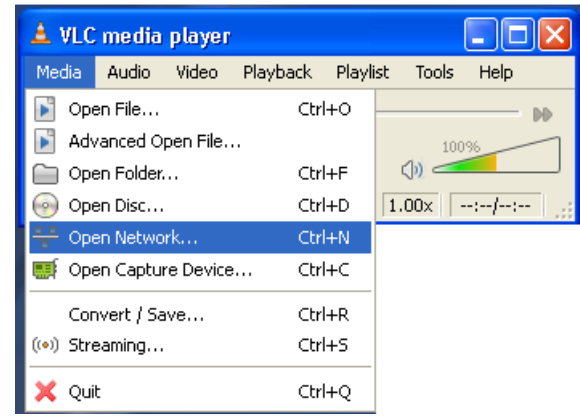

Gambar 10. Tampilan menu File VLC

* Memilih kotak dialog network

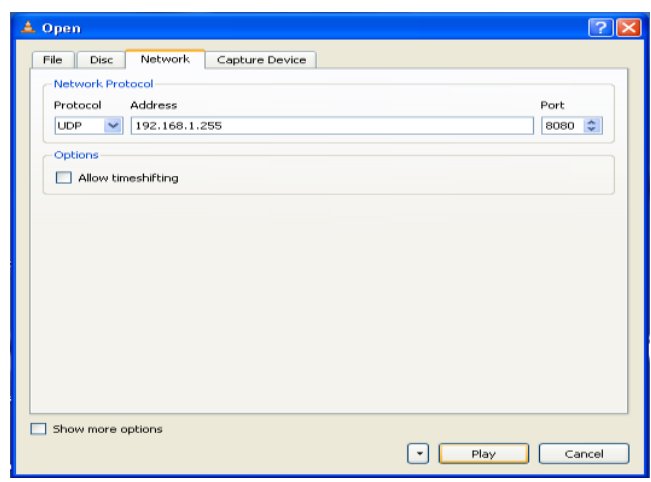

Gambar 11. Tampilan Menu Network VLC media player.

Dari tampilan menu network maka dapat mengisi IP broadcast dari server yaitu 192.168.1.255 dan port 8080 . Kemudian akan muncul siaran yang 
terdapat pada satelit Telkom-1 sesuai dengan data yang di broadcast dari server.

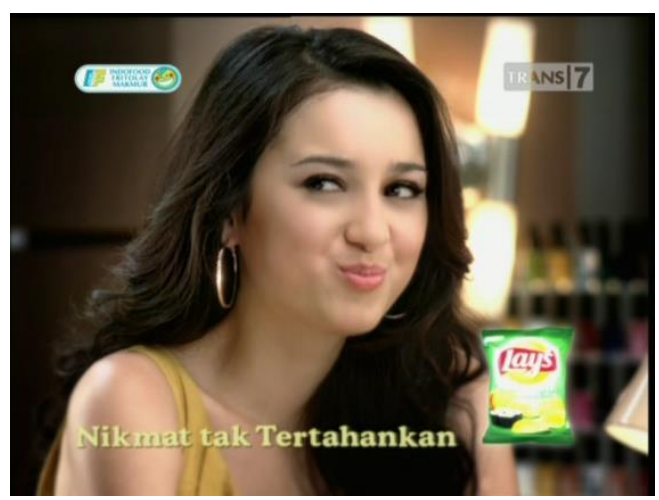

Gambar 12. Tampilan siaran sesuai dengan yang di broadcast dari server.

\section{IP Address}

Untuk IP address yang digunakan pada saat broadcast adalah IP address kelas C yaitu dalam range 192.0.0.0223.255.255.255. Metode pemberian IP address pada komputer dilakukan secara manual atau statis.

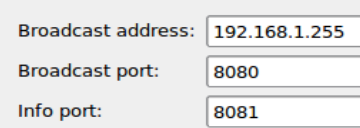

Gambar 13. IP Kelas C.

\section{Metode Pengiriman Data}

Metode broadcast ini adalah jenis transmisi dimana informasi dikirim dari satu komputer pengirim (server) dan diterima oleh semua komputer client yang terhubung ke jaringan. Disini server mengirimkan data pada jaringan secara terus menerus tanpa melakukan pengecekan apakah client siap atau tidak, atau tanpa memperhatikan data tersebut sampai atau tidak. Berikut adalah cara kerja metode broadcast.

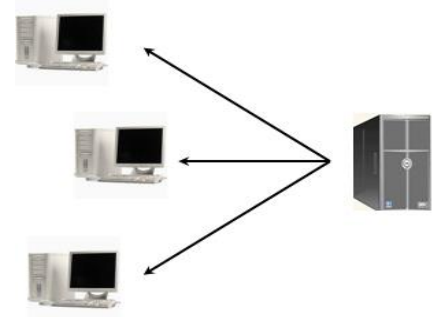

Gambar 14. Cara Kerja Metode Broadcast.

\section{Analisa Hasil Pengamatan}

Proses analisa dilakukan dengan cara melihat parameter Lost Frame, Lost Buffer dan Stream Bitrate yang tampil di sisi client atau pengguna. Semakin besar nilai Lost Frame, Lost Buffer dan Stream Bitrate maka kualitas layanannya kurang baik. Berikut ini tabel hasil pengamatan streaming TV channel pada sisi client.

Tabel 1. Hasil Pengamatan lost frame, buffer

\begin{tabular}{|c|c|c|c|c|c|}
\hline \multirow{2}{*}{ No } & \multirow{2}{*}{ Waktu } & Video & \multicolumn{2}{|c|}{ Input } \\
\cline { 3 - 5 } & & $\begin{array}{c}\text { Lost } \\
\text { Frame }\end{array}$ & $\begin{array}{c}\text { Lost } \\
\text { Buffer }\end{array}$ & $\begin{array}{c}\text { Stream } \\
\text { Bitrate } \\
(\mathrm{kb} / \mathrm{s})\end{array}$ & \multirow{2}{*}{ Keterangan } \\
\hline 1 & 10.30 .00 & 63 & 0 & 6613 & Baik \\
\hline 2 & 11.00 .00 & 2694 & 0 & 6627 & Baik \\
\hline 3 & 11.30 .00 & 3798 & 0 & 6645 & Baik \\
\hline 4 & 12.00 .00 & 5528 & 0 & 6775 & Baik \\
\hline 5 & 12.30 .00 & 6629 & 0 & 6604 & Baik \\
\hline 6 & 13.00 .00 & 8615 & 0 & 6636 & Baik \\
\hline 7 & 13.30 .00 & 10069 & 0 & 6650 & Baik \\
\hline 8 & 14.00 .00 & 11891 & 0 & 6732 & Baik \\
\hline 9 & 14.30 .00 & 13934 & 0 & 8124 & Baik \\
\hline 10 & 15.00 .00 & 16489 & 0 & 6497 & Baik \\
\hline
\end{tabular}

Suatu jaringan dapat disebut ideal apabila mampu mengirimkan informasi apapun, tidak terbatas jumlah dan ukuran, serta tanpa menimbulkan delay ataupun loss. Akan tetapi dalam prakteknya akan sangat sulit untuk menciptakan jaringan dengan karakteristik seperti itu, 
terbatasnya bandwidth merupakan hal yang bersifat temporal. Faktor performansi dari sistem video streaming dalam hubungannya dengan jaringan dapat dijelaskan sebagai berikut:

\section{- Stream Bitrate}

Aplikasi streaming TV Channel membutuhkan bitrate yang cukup tinggi, hal ini menyebabkan beban jaringan bertambah sehingga service yang diberikan tidak dapat berjalan dengan baik (terganggu). Selain masalah pada bitrate, masalah terbesar yang dihadapi dari teknologi ini adalah keterbatasan bandwidth, sedangkan proses komunikasi menggunakan digital video ini menghabiskan resource yang cukup besar.

\section{* Lost Buffer}

Apabila data video menghabiskan terlalu banyak waktu pada saat berada di jaringan, maka hal tersebut akan menjadi tidak berguna, meskipun data video tersebut pada akhirnya berhasil diterima oleh client. Hal ini disebabkan di sisi client sistem masih melakukan proses decoding dan menampilkan video tersebut, sehingga total waktu yang dihabiskan akan terlalu lama untuk dapat disebut sebagai realtime. Lost buffer pada Tabel 1 menunjukkan bahwa kualitas siaran yang diterima client bagus, hal ini karena lost buffer bernilai 0 sehingga hasil streaming yang diterima maksimal.

\section{* Lost Frame}

Hilangnya sebagian dari data video yang dikirimkan melalui jaringan dapat disebabkan oleh banyak hal, seperti penolakan oleh sistem karena delay yang terlalu lama, ataupun kesalahan pada jaringan itu sendiri. Suatu sistem video streaming tidak dapat mengabaikan kemungkinan terjadinya data error ataupun data loss selama proses transmisi, karena akan mengakibatkan kualitas yang buruk dari video pada saat ditampilkan. Loss yang terjadi pada jaringan dapat mengakibatkan keadaan yang lebih buruk di sisi client, misalkan paket data pertama dari frame-frame video yang ditransmisikan itu rusak atau hilang selama berada di jaringan, maka seluruh paket data sisanya tidak akan dapat ditampilkan meskipun berhasil dikirimkan dan diterima oleh client.

\section{KESIMPULAN}

1. Metode multicast merupakan metode untuk mengirimkan informasi kepada seluruh host yang ada pada jaringan yang sama dengan mencantumkan satu multicast address sebagai destination address dari informasi yang dikirimkan.

2. Kebutuhan bandwidth sangat mempengaruhi terhadap hasil streaming TV channel pada jaringan Wireless LAN Akatel Sandhy Putra Purwokerto, hal ini karena bandwidth yang dibutuhkan terbatas, dan cenderung berubah-ubah terhadap waktu.

3. Sudut Azimuth dan Elevasi diperlukan untuk membantu mengarahkan posisi antena stasiun bumi ke arah antena 
satelit, sehingga tidak terjadi pointing loss.

4. Media Player yang digunakan pada server untuk melakukan broadcast TV Channel ke komputer client yaitu Kaffeine Player 0.8.7.

5. Media Player yang digunakan untuk menerima streaming TV Channel pada client yaitu VLC dengan versi minimalnya adalah 9.0.

6. Hasil siaran TV streaming ini tidak sempurna karena adanya beberapa parameter yang mempengaruhinya diantaranya bandwidth, delay dan error.

\section{DAFTAR PUSTAKA}

[1] Annonymus. 2010. Postel "Draft White Paper IPTV"

[2] Anton. 2005. Protokol Multimedia dan Qos. Fakultas Teknik Informatika. Universitas Kristen Duta Wacana.

[3] Annonymus. 2004. RTSP (Real Time Streaming Protocol)

http://www3.rad.com/networks/2004/RTS

P/main/frame.htm diakses pada tanggal 28 Juni 2010, 18:30 WIB.

[4] Agustomo. 2009. Jaringan Protokol H.323 http://bisnistypeapproval.wordpress.com/ta g/protokol-h-323/

diakses pada tanggal 18 Juni 2010, 6:06 WIB.

[5] Ahmad, Fikri. 2008. Session Initiation Protocol (SIP) http://www.ittelkom.ac.id/library/index.ph p?view $=$ article $\&$ catid $=10 \% 3$ Ajaringan $\&$ id $=157 \% 3$ Asession-initiation-protocol$\underline{\text { sip\&option }=\text { com_content } \& \text { Itemid }=15}$ diakses pada tanggal 25 Juni 2010, 21:14 WIB.

[6] Azikin, dkk. 2005. Video/TV Streaming dengan VideoLAN Project, Penerbit ANDI, Yogyakarta, 152 halaman.

[7] Cisco Press. 2003. 802.11 Wireless LAN Fundamentals. Indianapolis USA : Cisco Systems, Inc., Publication.

[8] Febrian, Jack. 2004. Kamus Komputer dan Teknologi Informasi. Bandung : Penerbit Informatika.

[9] Held, Gilbert. 2007. Understanding IPTV. USA : Auerbach Publications.

[10] Nursupangkat. 2004. Teknologi Perlindungan Isi pada DVB, http://www.cert.or.id/ budi/courses/ec701 0/dikmenjur2004/nursupangkat-report.pdf diakses pada tanggal 21 April 2010, 16:35 WIB.

[11] O'driscoll, Gerard. 2008. Next Generation IPTV Services And Technologies. Canada : A John Wiley \& Sons, Inc., Publication.

[12] Purbo, Onno W. Komunikasi Multicast Dalam Dunia Network, http://onno.vlsm.org/v11/ref-ind1/network/komunikasi-multicast-dalamdunia-network-1999.pdf diakses pada tanggal 17 April 2010, 13:20 WIB.

[13] Sugiyono. 2008. Metode Penelitian Kuantitatif Kualitatif dan $R \& D$. Penerbit Alfabeta. 